\title{
Microencapsulation Technology of Ginger Oleoresin With Chitosan as Wall Material: A review
}

\author{
Jayanudin $^{1,2^{*}}$, Rochmadi ${ }^{1}$, Moh. Fahrurrozi ${ }^{1}$, Sang Kompiang Wirawan ${ }^{1}$ \\ ${ }^{1}$ Chemical Engineering Department, Faculty of Engineering, Gajah Mada University, Yogyakarta 55281, Indonesia. \\ ${ }^{2}$ Chemical Engineering Department, Faculty of Engineering, Sultan Ageng Tirtayasa University Jl. Jenderal Sudirman km.3 Indonesia.
}

\section{ARTICLE INFO}

Article history:

Received on: 30/09/2016

Revised on: $17 / 10 / 2016$

Accepted on: 16/11/2016

Available online: $28 / 12 / 2016$

\section{Key words:}

Coacervation, Chitosan,

Ginger oleoresin,

Microencapsulation, Spray

drying.

\begin{abstract}
Ginger oleoresin is a product of ginger extraction using an organic solvent. Ginger oleoresin can be used in the pharmaceutical and food industry because it tastes the same as the original material, but more concentrated and also contains active components such as shogaol, gingerol which are sensitive to environmental influences so easily oxidized. Appropriate protection for ginger oleoresin is by microencapsulation. Microencapsulation is the process of protecting the active ingredient in the form of gas, liquid and solid by the use of coating material. The main objective was for the protection of microencapsulated active ingredients and release control by controlling the dissolution rate of the coating material. Microencapsulation method can be done in physics such as spray drying or chemically as coacervation. The type of coating used is not toxic, biocompatible and biodegradable polymers such as chitosan which is natural and safe for consumption. Rate of release can be done by determining the release kinetics using several models such as the model of zero order, first order, Higuchi models, Korsmeyer-Peppas and Hixon-Crowell.
\end{abstract}

\section{INTRODUCTION}

Microencapsulation is a technology used to protect the active ingredient in the form of liquid, solid and gas from environmental affect. The active ingredients as the core protected by a coating material (Ghosh, 2006; Dubey, et al., 2009; Venkatesan, et al., 2009; Bansode, et al., 2010; Jyothi, et al., 2010). Microencapsulation technology is used in several industries such as chemical, pharmaceutical, cosmetics and inks. In the 1950s, microencapsulation for the first time applied in carbonless copying paper industry with complex coacervation method using a coating of gelatin and gum arabic as wall material that has been done by Green and Schleicher (Dubey, et al., 2009). Sahidi and Han (1993) have been said that there were six objective of the encapsulation process in the food industry or medicine, namely: 1) can reduce the reactivity of the core material to the environment, 2) reducing the rate of transfer of

* Corresponding Author

E-mail: jayanudin@ untirta.ac.id the core material to the environment, 3 ) ease the handling process, 4 ) the controlled release of the core material, 5) cover the taste of the core material and 6) can melt the core material, if required for use in a few minutes. The microcapsules are small granules with a uniform coating around it. Materials that are within the microcapsules are referred to as the core, while the wall is called a shell, layer, coating or membrane (Poshadari and Kuna, 2010).

The development of microencapsulation technology continues to evolve and is widely used in many fields and is the most popular in the the pharmaceutical field (Dubey, et al., 2009), especially the extraction of natural ingredients that are usually sensitive to light, heat and microorganisms, so it is easily oxidized and degraded. The same thing also happened in oleoresin ginger, resulting from the extraction of ginger using an organic solvent, ginger oleoresin contains volatile components as the components contained essential oils of ginger and components of non-volatile as gingerol (Onyenekwe, 2000; Lun et al., 2008; Nwaoha et al., 2013) and shogaol formed from dehydration gingerol during the heating process or storage (Bhattarai et al., 2007; Ali et al., 2008; Wohlmuth et al., 2005). 
Ginger oleoresin components such as shogaol, gingerol and zingerone is a major component in ginger oleoresin and these components are sensitive to environmental influences that need to be protected. The method used to protect the active component is coated capsules of gelatin. Gelatin capsules are divided into hard gelatin capsules and soft gelatin capsules. Another method is to use microencapsulation; this method uses a coating polymer synthetic or natural polymer, the product powder form micrometer to nanometer size.

Advantages of bioactive protection to the ginger oleoresin microencapsulation method is a process for controlled release in the body or stability in the body, while the bioactive coated in gelatin capsules dissolve uncontrollably with great concentration. The main function of the encapsulation is a controlled release, which is defined as a method of release of one or more active ingredients are available at the desired part and with a certain speed.

Control release depends on several factors such as the diffusion of the active compound through the matrix, type and particle geometry, the transfer from the matrix to the environment and degradation of matrix with dissolution (Pothakamury and Barbosa-Canovas, 1995).

\section{MICROENCAPSULATION OF GINGER OLEORESIN}

\section{Ginger oleoresin}

Oleoresin ginger is ginger product using organic solvent extraction, oleoresin containing volatile compounds and nonvolatile compounds (Stahl, 1973), oleoresin form of a viscous fluid and usually sticky and reddish brown (Reineccius, 1994). The main component of oleoresin ginger is gingerol and shogaol which give the spicy taste of ginger. Gingerol and shogaol will affect the quality of ginger (Ravindran et al., 2004), in general, the content of gingerol and shogaol in ginger is $14.0-27.0 \%$ and $2.7-7.5 \%$
(Ravindran et al., 1994). The Yield of ginger oleoresin depends on the type of solvent usage, extraction operating conditions, the condition of the ginger rhizome (wet or dry), country of origin ginger, and weather factors (Vernin and Parkanyi, 2004). The amount of yield obtained ranges between $3-11 \%$ could even reach $20 \%$, the research that has been done by Jayanudin, et al. (2013) obtained red ginger oleoresin yield of $13 \%$ and based on the results obtained The Gas Chromatography Mass Spectrometry (GCMS) analysis of 45 components with main component was shogaol and zingerone. Figure 1 shows the results of GCMS analysis for red ginger oleoresin using methanol as solvent.

The research conducted by Magalhaes et al. (1997) with ginger from various areas in Brazil, using three different solvents. Results for oleoresin are given in Table 1, the highest percentage of oleoresin using ethanol as a solvent. Pungent flavor of ginger oleoresin is (6)-gingerol, $1 \mathrm{~b}$ (1- [4-hydroxy-3-methoxyphenyl] -5hydroxydecane-3-ol), which was first identified by Lapworth (1917) and by Connell and Sutherland (1969). The name of (6)gingerol was derived from the fact that alkaline hydrolysis of gingerol given n-hexanal -a six-carbon aldehyde. In addition to the presence of well-known (6)-, (8)-, and (10)-gingerols.

Table 1: Percentages of oleoresin from various areas in Brazil with different solvent

\begin{tabular}{lll}
\hline No & Solvents & Oleoresin $(\%)$ \\
\hline 1 & Ethanol & $6.91-10.9$ \\
2 & Acetone & $2.53-5.62$ \\
3 & Methylene chloride & $3.35-3.91$ \\
\hline
\end{tabular}

Ginger oleoresin containing the active components which have many benefits, so it is widely used in various industries such as food, cosmetics, and pharmaceuticals. Many research using bioactive components of ginger to the antioxidant, antimicrobial and even anticancer (Nielsen and Raos, 200; Gutieerez et al., 2008; Murthy et al., 2015; Bailey-shaw et al., 2008).

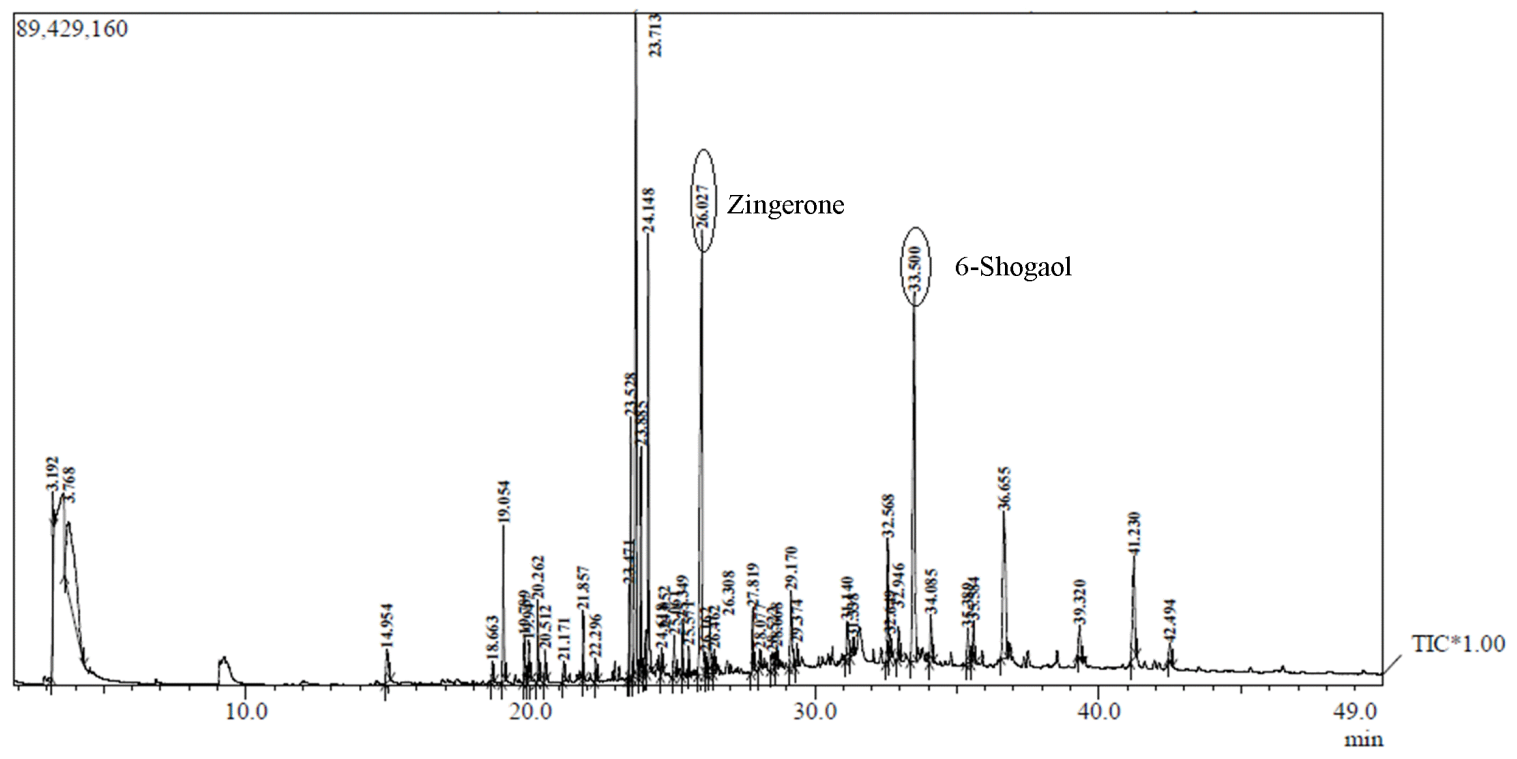

Fig. 1: Analysis red ginger oleoresin using Gas Chromatography Mass Spectrometry (GCMS). 
Properties of ginger oleoresin are sensitive to environmental effects such as heat, air, microorganisms which can cause degradation and reduce the benefits of ginger oleoresin. This is caused by changes in polymer involving fat and oil component of hydrocarbon monoterpenes (Balasubramani et al., 2013; Shaikh et al., 2006; Vaidya et al., 2006). The way to solve the problem, it can be done with the encapsulation process (Vaidya et al., 2006). According to Mishra (2016) there are several reasons to use another method of encapsulation to protect bioactive, which are:

1. Protect the core material from degradation due to environmental influences (UV rays, heat, air oxidation, the effect of acid and alkaline chemicals, etc.).

2. Improve the visual aspect and a marketing concept to the final product

3. Reduce evaporation or transfer rate of volatile compounds (core material) into the environment.

4. Modify the physical characteristics of materials making it easy to handle (e.g, converting the liquid into a solid, capable of overcoming the sticky material properties).

5. The achievement of the target of control/ release of the active ingredient. This product can be customized to release slowly over time or to reach a certain point. Increase shelf life by preventing degradation reactions.

6. Protect the taste and smell of bioactive.

7. Handling precious active ingredients (this material may be diluted gradually in small amounts, but still achieving uniform dispersion of large amounts of material.

8. Mixing of incompatible materials by separating components in a mixture which will react with one another.

9. Improved processing of materials (texture and reduced material wastage, controlling hygroscopic, improve solubility, dispersion and dust-free powder)

10. Safe handling of toxic materials

\section{Classification of microencapsulation}

Classification of microcapsules based on the size and morphology, for its size ranging from $1 \mu \mathrm{m}$ to nanometers. The particle size of between 3 and $8 \mu \mathrm{m}$, referred to microcapsules, microparticle or microsphere. Particles larger than $1000 \mu \mathrm{m}$ referred to macroparticle (Mishra, 2016).

Table 2: Particle size based on the encapsulation method.

\begin{tabular}{llll}
\hline No & Encapsulation method & $\begin{array}{c}\text { Particle size } \\
(\boldsymbol{\mu m})\end{array}$ & \multicolumn{1}{c}{$\begin{array}{c}\text { Maximum loading } \\
(\boldsymbol{\%})\end{array}$} \\
\hline 1. & Simple coacervation & $20-200$ & $<60$ \\
2. & complex coacervation & $5-200$ & $70-90$ \\
3. & Spray drying & $1-50$ & $<40$ \\
4. & Spray chilling & $20-200$ & $10-20$ \\
5. & Extrusion & $200-2000$ & $6-20$ \\
6. & Fluidised bed & $>1000$ & $60-90$ \\
\hline
\end{tabular}

Source: Madene, 2006

The particle size may also depend on the method of encapsulation process, the following Table 2 is various particle sizes of several methods of encapsulation. Classification of the microcapsules is also dependent on the core material, the distribution system, and the deposition of the coating process. Morphology microcapsules also depend on the coating material and method of microencapsulation. According to Mishra (2016) and Dubey et al., (2009) microcapsules can be categorized into several classifications, such as

a. Single core: microcapsules having a single hollow chamber inside the capsule,

b. Multi core: these microcapsules have many cores enclosed with in the shell

c. Matrix: microcapsules of this type. The core material id distributed homogeneously within the wall material

From the three categories there are also single core with multi shell and multicore with multi shell. Types of morphology will affect the release process. Single coating (single shell) will differ release process with multi shell. This morphology adjusted to the needs and the desired release. Microcapsules with a coating of more than one will be more stable as compared with only one coating, in Figure 2 shows the classification of microcapsules.

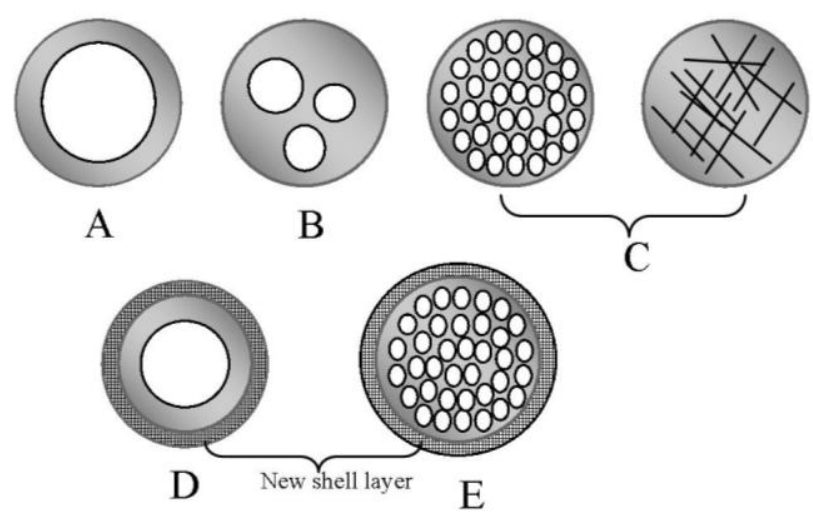

Fig. 2: Type microcapsules, A. Monocore (Reservoir); B. Multicore; C. Matrix; D. Coated monocore-type Core-Shell; E. Coated matrix.

Composition, release mechanism, the particle size and form of the microcapsules depends on the desired application. The shell or shell material effect on the stabilization of core materials and are inert to the active ingredient. The shell can be a filmformingit has no sense, stable, non-hygroscopic, economical, and soluble in aqueous media and solvents. The shell material could be flexible, brittle, hard, thin and others. System microcapsules system can increase shelf life of bioactive and controlled release (Zuidam and Shimoni, 2010). In Table 3 explains about morphology of microcapsules based encapsulation method.

Table 3: Morphology microcapsules on various methods of encapsulation.

\begin{tabular}{lllll}
\hline No & Encapsulation method & Morphology & $\begin{array}{c}\% \\
\text { loading }\end{array}$ & $\begin{array}{c}\text { Particle } \\
\text { size }(\boldsymbol{\mu m})\end{array}$ \\
\hline 1 & Spray drying & Matrix & $5-50$ & $10-400$ \\
2 & Fluid bed coating & Reservoir & $5-50$ & $5-5,000$ \\
3 & Coacervation & Reservoir & $40-90$ & $10-800$ \\
4 & Spray-chilling/ Cooling & Matrix & $10-20$ & $20-200$ \\
5 & Melt injection & Matrix & $5-20$ & $200-2,000$ \\
6 & Freeze/vacuum Drying & Matrix & Various & $20-5,000$ \\
\hline
\end{tabular}

Source: Zuidam and Shimoni, 2010 


\section{Microencapsulation method}

Microencapsulation process is the protection of active ingredient (bioactive) from environmental influences using the coating material in the form of polymers or biopolymers. Microencapsulation is a product in the form of micrometer-sized powder, microcapsules protection methods different from bioactive protective capsule, which capsule is in the form of hard and soft shell is usually made of gelatin. Shell (capsule) is a drug delivery that is easy to swallow, tasteless and odorless (De Villiers, 2005). The capsules can also be used to store and protect of ginger oleoresin, type of capsule that is appropriate to protect oleoresin shaped pasta is soft capsules, hard capsules used due to solids. Soft gelatin capsules (soft gelatin) made of gelatin films is more flexible than hard gelatin capsules, as seen in Figure 3, bioactive are in soft gelatin capsule. According to De Villiers (2005) are some of the advantages and disadvantages of using the protection of soft gelatin capsules are:

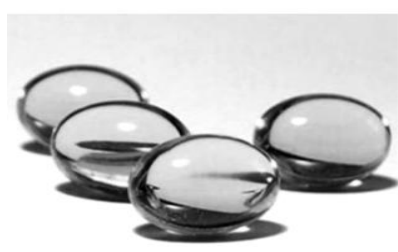

Fig. 3: Soft gelatin capsules

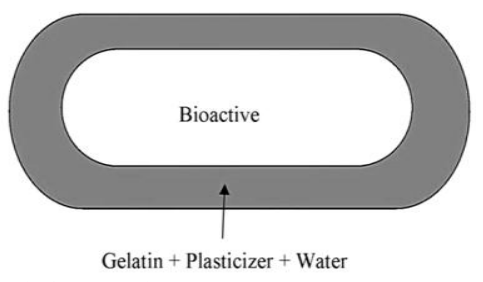

latin + Plasticizer + Water

A. Advantages of soft gelatin capsules

- Can be release quickly and the right choice for promoting dispersion of the capsule contents rapidly and dissolution of drug

- The soft gelatin capsules sealed making it suitable for drugs volatile

- The soft gelatin capsules are available in various sizes and shapes

- A higher degree of homogeneity is possible in liquid systems than can be achieved in powder blends.

B. Advantages of soft gelatin capsules

- a soft gelatin capsule dosage form of the drug is not cheap

- The possibility of direct contact between the contents of the capsule and the shell so that it can be possible interactions

- The drug can migrate from the oily vehicle in the capsule shell and this has been associated with water solubility and partition coefficient between water and non-polar solvents. Migration of these drugs should be considered because it can affect the concentration of the drug.

One fundamental difference between protection with soft and hard gelatin capsules with microcapsules is a process of slow release or controlled target achievement of the active ingredient, so that the concentration of the release slowly. Unlike the bioactive in soft and hard gelatin capsules to be dispersed with great concentration after shell gelatin is dissolved.

The process of drug delivery with capsule is not suitable for ginger oleoresin, because of the nature of ginger oleoresin poorly soluble in water so that when the shell gelatin is dissolved, and ginger oleoresin will come out of the shell but not soluble in water so that the body is unable to absorb. The exact method for the protection of oleoresin is a microencapsulation method, in addition to protecting the ginger oleoresin with a coating can also improve the water solubility, and because entrapped in the coating can be dissolved in water.

Selection of the encapsulation process depends on the physical and chemical properties of the core and shell of the microcapsules (Mishra, 2016), a wide variety of encapsulation methods have been developed for a variety of functions. In general, encapsulation method is divided into two, namely the encapsulation process with chemical and physical methods, in Table 4 shows several methods of physical and chemical encapsulation.

In general, the same encapsulation method has different techniques is that after the process of forming the emulsion. Encapsulation process after the formation of emulsions can be made using physically or chemically depending on the needs. Here are some techniques or methods that may be used for the encapsulation process:

Table 4: Encapsulation method.

\begin{tabular}{lll}
\hline Encapsulation method & Particle size $(\boldsymbol{\mu m})$ \\
\hline \multirow{3}{*}{ Chemical method } & Simple coacervation & $20-200$ \\
& Complex coecervation & $5-200$ \\
& Molecular inclusion & $5-50$ \\
\hline \multirow{3}{*}{ Physical methods } & Spray drying & $1-50$ \\
& Spray chilling & $20-200$ \\
& Extrusion & $200-2000$ \\
& Fluidised bed & $>100$ \\
\hline
\end{tabular}

Source: Madene, et al (2006).

\section{Spray drying}

Spray drying is a process of change from a liquid into a dry powder by contacting medium heat (hot air), the feed can be suspension, emulsions and pastes in which the powder properties depend on physical and chemical properties (Keshani, et al., 2015). Spray drying is the oldest method of microencapsulation in food industry and was discovered in 1930 (Dziedzak, 1988). Spray drying is the process of spraying the material through the atomizer and contacted with hot air to produce powder with $10-50 \mu \mathrm{m}$ size and the largest size particle is $2-3 \mathrm{~mm}$ (Gharsallaoui, 2007).

Powder result of the spray dryer has good characteristics, has a little water content and good storage process. Spray drying can also be used for components that are heat sensitive. Wall material for coating such as maltodextrin, gum Arabic and gelatin have been successfully performed using a spray dryer (Mishra, et al., 2014). Another advantage of spray drying is its ability to produce a powder with particle size and moisture content with a 
specific value, regardless of dryer capacity. Spray dryer can be operated continuously and easily with an automatically controlled and requires a short time (Keshani, et al., 2015). Figure 4 shows the steps of spray drying.

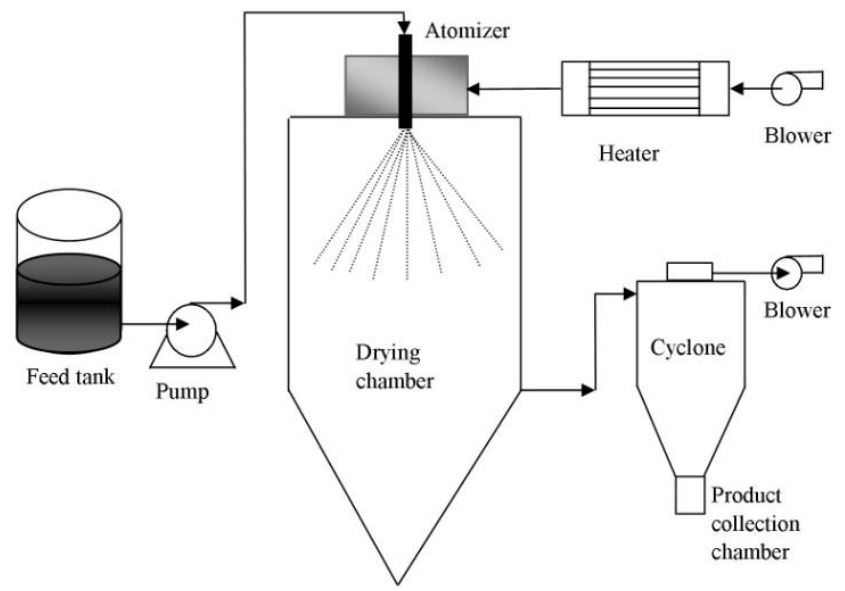

Fig. 4: Spray drying process

Table 5: Microencapsulation of ginger oleoresin with spray drying

\begin{tabular}{|c|c|c|c|c|c|}
\hline z & 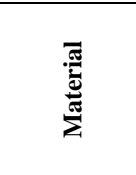 & 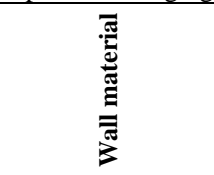 & 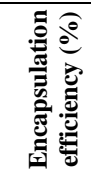 & 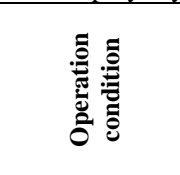 & 怤 \\
\hline 1 & $\begin{array}{l}\text { Oleoresin } \\
\text { of dregs } \\
\text { ginger }\end{array}$ & Maltodextrin & 22.13 & $\begin{array}{l}\text { A feed rate of } \\
15 \mathrm{ml} / \mathrm{min} \text { and } \\
\text { an inlet } \\
\text { temperature of } \\
120^{\circ} \mathrm{C}\end{array}$ & $\begin{array}{l}\text { Nurlaili } \text { et al., } \\
2014\end{array}$ \\
\hline 2 & $\begin{array}{l}\text { Ginger } \\
\text { extract }\end{array}$ & $\begin{array}{l}\text { Maltodextrin : } \\
\text { gum arabic }\end{array}$ & $33-40$ & $\begin{array}{l}\text { Inlet } \\
\text { temperature of } \\
160^{\circ} \mathrm{C}\end{array}$ & $\begin{array}{l}\text { Simon-Brown } \\
\text { et al., } 2016\end{array}$ \\
\hline 3 & $\begin{array}{l}\text { Ginger } \\
\text { oleoresin }\end{array}$ & $\begin{array}{l}\text { Maltodexrin and } \\
\text { sodium caseinate }\end{array}$ & - & $\begin{array}{l}\text { A feed rate } 15 \\
\text { and } 20 \mathrm{~mL} / \mathrm{min} \text {. } \\
\text { Inlet } \\
\text { temperature of } \\
160-190{ }^{\circ} \mathrm{C}\end{array}$ & $\begin{array}{l}\text { Yuliani et al., } \\
2007\end{array}$ \\
\hline 4 & $\begin{array}{l}\text { Ginger } \\
\text { Oleoresin }\end{array}$ & $\begin{array}{l}\text { Maltodexrin and } \\
\text { sodium caseinate }\end{array}$ & - & $\begin{array}{l}\text { Inlet } \\
\text { temperature of } \\
160^{\circ} \mathrm{C} \text { and } \\
\text { outlet } 100{ }^{\circ} \mathrm{C}\end{array}$ & $\begin{array}{l}\text { Harimurti } \\
\text { et al., } 2011\end{array}$ \\
\hline 5 & $\begin{array}{l}\text { Red ginger } \\
\text { Oleoresin }\end{array}$ & $\begin{array}{l}\text { Chitosan : Sodium } \\
\text { alginate }\end{array}$ & 70.59 & $\begin{array}{l}\text { Inlet } \\
\text { temperature of } \\
180^{\circ} \mathrm{C}\end{array}$ & $\begin{array}{l}\text { Jayanudin } \\
\text { et al., } 2015\end{array}$ \\
\hline
\end{tabular}

In Table 5 below are studies that have been done by using spray drying for the encapsulation process of ginger oleoresin. According Anandharamakrishnan and Padma (2015) using the spray drying microencapsulation is divided into three steps:

1. Atomization of the feed

2. Contact of spray with hot gas to evaporation of moisture

3. Particle separation

Spray dryer operates by convection. The basic principle is to eliminate of moisture with the application of heat to the feed and control the moisture with a drying medium. Evaporation of moisture is promoted by spraying the feed into a heated atmosphere. The spray drying process will be more easily understood, if it is divided into its constituent operating units. Spray drying is the encapsulation method the most widely performed because it is more flexible, simple operation, continuous, rapid and economical (Cerqueira, et al., 2015). Table 6 describes the advantages and disadvantages of the spray drying for the encapsulation process.

Table 6: Advantages and disadvantages of spray drying method.

\begin{tabular}{lll}
\hline Method & \multicolumn{1}{c}{ Advantages } & \multicolumn{1}{c}{ Disadvantages } \\
\hline & - Continuous Production: dry & - The limited availability \\
particles are stored & and high cost of the coating \\
continuously under spray & or encapsulation material \\
drying & - Requires high temperature \\
& - The operation is easy: & during the process \\
& constant product quality & - The level of oil loading is \\
because of constant operating & low and the difficulty of air \\
& conditions & inclusions in the process of \\
& - Low cost & emulsification \\
- A wide selection of carrier & - During the process, the \\
material and equipment & active ingredient aroma is \\
& - Mechanical friendly for food & likely that some missing \\
manufacturers & - The active ingredient is \\
& - Increase expired time & made possible oxidized \\
- Methodology relatively & during the drying process \\
smooth for the solvent and & \\
matrix molecule applications & \\
\hline Source: Cerqueira, et al., 2015; Zuidam and Heinrich, 2010.
\end{tabular}

\section{COACERVATION}

Coacervation method is the encapsulation process was first patented in 1950 for carbonless paper, this technique is considered as the original method of encapsulation. The liquid phase of the wall material material or coating is separated from the polymer solution and then coating surrounds the core material solidified (Risch, 1995).

Coacervation consists of separation solution colloidal particles then coagulates into a separate, so-called melting phase coacervate (Madene, 2006). Generally, the core material used in coacervation must be compatible with the excipient polymer and insoluble (or hardly soluble) in media coacervation.

For complex coacervation, flavor ingredients must be present in the mixture as a result of core coacervate coacervation and then adsorbed onto the surface of volatile compounds. The addition of flavor can be done during the separation process or thereafter. Coacervation process must constantly stirred and added stabilizer to avoid freezing microcapsules (Madene, et al., 2006; Arshady, 1999).

\section{Simple coacervation}

Simple coacervation can be accomplished by the addition of chemical compounds with high affinity for water such as salt and alcohol. The principle is to be carried in a polymer solution when the temperature, $\mathrm{pH}$, solvents and salts are chosen correctly. The level of hydration is the most important factor of this process. Substances that are added can lead to the formation of two phases, 
the first colloidal droplets rich and others poor (Wise, 2000; Nixon, et al., 1966). Microencapsulation process with simple coacervation method with the following steps (Wise, 2000):

1. Distribution of core material in the polymer solution

2. Make a shortage of water for hydrophilic colloids and deposition coacervate around the core

3. Gelation of coacervate and hardening of the microcapsules

Desolvation polymers on simple coacervation can be induced by adding inorganic salts, this phenomenon is called salting-out. Inorganic cations ability to induce coacervation dictated by Hofmeister or lyotropic series is set in a capacity reduction of salting ion for polymers:

$\mathrm{Mg}^{+2}>\mathrm{Ca}^{+2}>\mathrm{Si}^{+2}>\mathrm{Ba}^{+2}>\mathrm{Li}^{+}>\mathrm{Na}^{+}>\mathrm{K}^{+}>\mathrm{NH}^{+}>\mathrm{Rb}^{+}>\mathrm{Cs}^{+}$

Several anion of the Hofmeister series in decreasing order of coacervation inducing the citrate, tartrate, sulfate, acetate, chloride, nitrate, bromide and iodide (Yan, 2016). Comparison between simple coacervation with a complex coacervation is lower cost and flexible operation. The process of phase separation, simple coacervation's just using inorganic salts, while complex coacervation more sensitive even at low $\mathrm{pH}$, hereinafter complex coacervation using hydrocolloids are relatively expensive (Sutaphanit and Chitprasert, 2014; Bakry, et al., 2016).

\section{Complex coacervation}

The basic principle of encapsulation by complex coacervation method is the ability of cationic and anionic polymers are soluble in water and interact in water to form a polymer-rich phase is called the complex coacervate (Yan, 2016). Complex Coacervation process involving different polymer charge and will neutralize (Wise, 2000), to produce a polymer-rich and polymer-poor. Polymer-rich will coat the core particles. Negatively charged of polymers are polysaccharides such as acacia, pectin, alginate, CMC (Carboxy methyl cellulose), positively charged polymers typically use proteins such as gelatin and chitosan (Kruif, et al., 2004; Saravan and Rao, 2010).

The most important thing to be aware of coacervation method is the polymer concentration, $\mathrm{pH}$, character of polymer and the core material. This will affect the desired end product (Saravan and Rao, 2010). According Lemetter, et al., (2009) produces microcapsules using complex coacervation method can consider four basic steps and illustrated in Figure 5, namely:

1. Dilution: prepare a solution containing two different polymers (e.g proteins and polysaccharides), usually above the temperature for gelation point of the protein and the $\mathrm{pH}$ is above the isoelectric point (pI) protein.

2. Emulsification / dispersion: emulsification of hydrophobic material (oil) above water solution. Emulsions stabilized by two polymers
3. Coacervation: the separation of the two liquid phases (phase rich in insoluble polymer and liquid phase and are reduced in both polymers) as a result of electrostatic interactions between the different polymer charges caused by a decrease in $\mathrm{pH}$ below the isoelectric point of the protein.

4. Gelation (gelling): formation of the coating/ wall due to deposition of polymer phase around droplets of hydrophobic material due to the cooling under temperature control gel

5. Hardening and rinsing/filtration/drying: cross link material used as glutaraldehyde to harden the walls of the microcapsules to stabilize the structure. Cross link material excess and residual oils that are not encapsulated or absorbed on the surface is removed by washing, and then dried to obtain a sample capsule powder.

The most important factor in the process is complex coacervation $\mathrm{pH}$ of the mixture, the ratio between the two polymers, the accessibility of charge for interaction and ionic strength. Effect of $\mathrm{pH}$ plays an important role in the process of complex coacervation because it affects the formation of proteincarbohydrate complex by affecting the degree of ionization of the functional groups of proteins (amino groups) and carbohydrates (carboxyl group). A mixture containing an anionic polysaccharide and protein, $\mathrm{pH}$ adjustments below the isoelectric point (PI) or electrical equivalence $\mathrm{pH}$ (IEP) maximizes the electrostatic attraction between the two polymers different charge (Schmitt, et al., 1998; Siow and Ong, 2013).

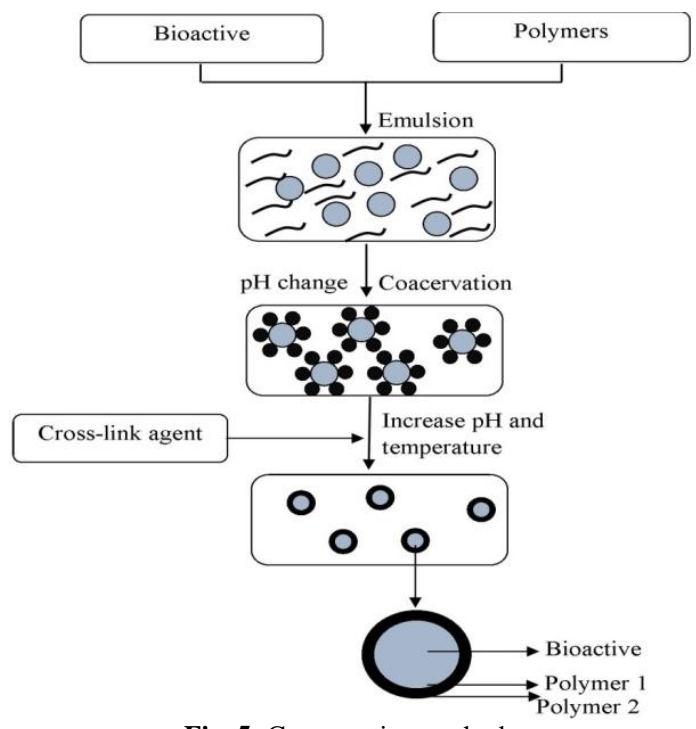

Fig. 5: Coacervation method.

The last stage of the process is the formation of wall coating coacervation, this process can be done with cross links, this process is needed to improve the mechanical properties, heat resistance and the release of microparticles wall. The process of 
cross links can be performed using chemical or enzyme (Burgess and Ponsart, 1998; Kruif, et al., 2004; Alvim and Grosso, 2010).

Based on the literature review, methods of coacervation to the encapsulation process oleoresin red ginger using a coating of chitosan has not been found, but the use of chitosan as a coating on the active components that others have already been studied, so that the information displayed is the use of chitosan as a coating and some cross link agent that can be used on coacervation process. Here is some cross link agent that can be used to crosslink chitosan:

\section{Glutaraldehyde}

Glutaraldehyde is widely used as a cross-link agent compared to other reagents, for easier and easily soluble in water (Jayakrishnan and Jameela, 1996). The use of glutaraldehyde is not recommended for food products because it is a high toxicity. Glutaraldehyde cross link agent is used for the dual function of binding sites of different reactions in chitosan. Glutaraldehyde cross link agent is used for the dual function of binding sites of different reactions in chitosan. Aldehyde group of glutaraldehyde forms a covalent bond of the imine with amino groups of chitosan, because the resonance is formed by bonding an ethylenic double adjacent through Schiff reaction.

Glutaraldehyde not only interact with amino groups can also interact with the carboxyl group and another group of proteins (Jayakrishnan and Jameela, 1996; Bowers and Cater, 1966; Anderson, 1967; Blauer et al., 1975). Figure 6 indicating the reaction of glutaraldehyde with chitosan.
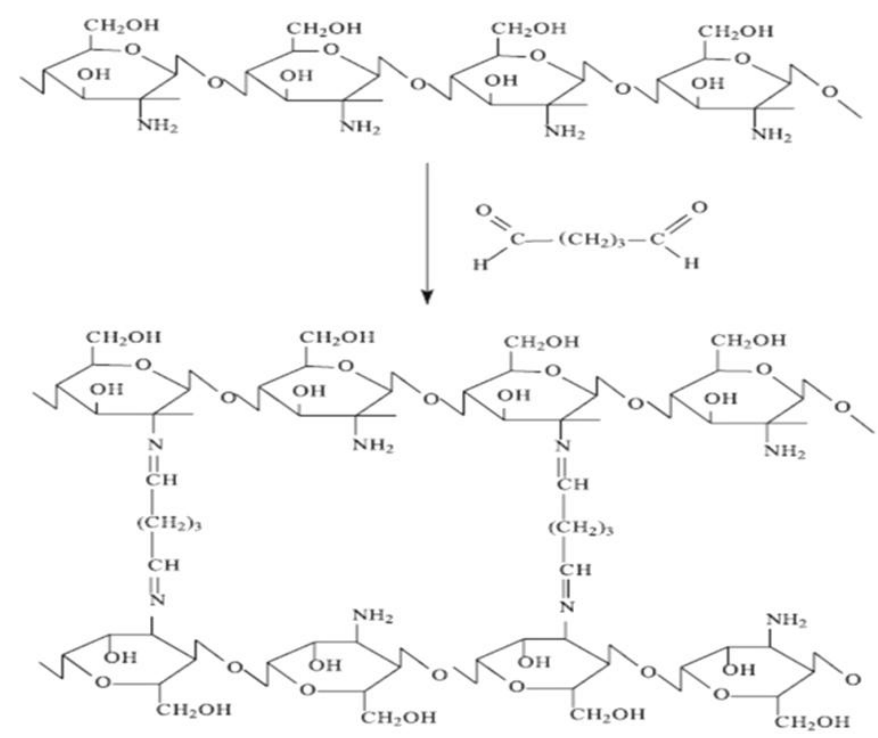

Source: Gonçalves., et al. 2005

Fig. 6: Cross-link reaction of chitosan with glutaraldehyde

Cross link agent of glutaraldehyde can be modified by mixing in toluene, called Glutaraldehyde Saturated Toluene (GST). This kind of cross link was first used by Longo et a1, 1982. GST is made by mixing glutaraldehyde and toluene with a volume ratio of 1: 1 and then stirred with a speed of 2000-3000 rpm for 1 hour, the mixture is allowed to stand overnight for an equilibrium process. The mixture will form two layers; a solution of GST is on the top layer.

The process of cross links are uniformly on the surface of the droplet is desired to produce a good sphericity, so the GST chosen as cross-link rather than glutaraldehyde, because their solubility in oil mediam be uniform to cross link the surface of the droplet. Droplet surface hardening by cross-link will improve the form and morphology of the microspheres surface, further crosslink can be done by adding glutaraldehyde after surface hardening process is achieved (Thanoo, et al., 1992).

\section{Tripolyphosphate (TPP)}

Tripolyphosphate (TPP), which comes from sodium tripolyphosphate (STPP), is multivalent anions are non-toxic, TPP is used as a cross link agent to form a cross-reaction between anion groups of TPP with positively charged amine groups of chitosan. The $\mathrm{pH}$ value of the solution TPP will affect the amount of negative group TPP. Decreasing $\mathrm{pH}$ value of TPP will increase the ionic cross-links between TPP and chitosan (Ko, et al., 2002; Yang et al., 2009).

Reaction cross link with chitosan TPP usually occurs at low $\mathrm{pH}$ because the TPP will be more ionized in ion form $-\mathrm{P}_{3} \mathrm{O}_{10}{ }^{-5}$ compared with $-\mathrm{OH}^{-}$hydroxy ions, in contrast to the high $\mathrm{pH}$, the TPP will be ionized in $-\mathrm{OH}^{-}$. The reaction between TPP and chitosan is ionically, namely the reaction between ions $-\mathrm{P}_{3} \mathrm{O}_{10}{ }^{-5}$ with $-\mathrm{NH}_{3}{ }^{+}$ions and ion $-\mathrm{OH}^{-}$with $-\mathrm{NH}_{3}{ }^{+}$are deprotonated $(\mathrm{Ko}$, et al., 2002; Bhumkar and Pokharkar, 2006). Figure 7 below is a reaction cross-link between TPP with chitosan.

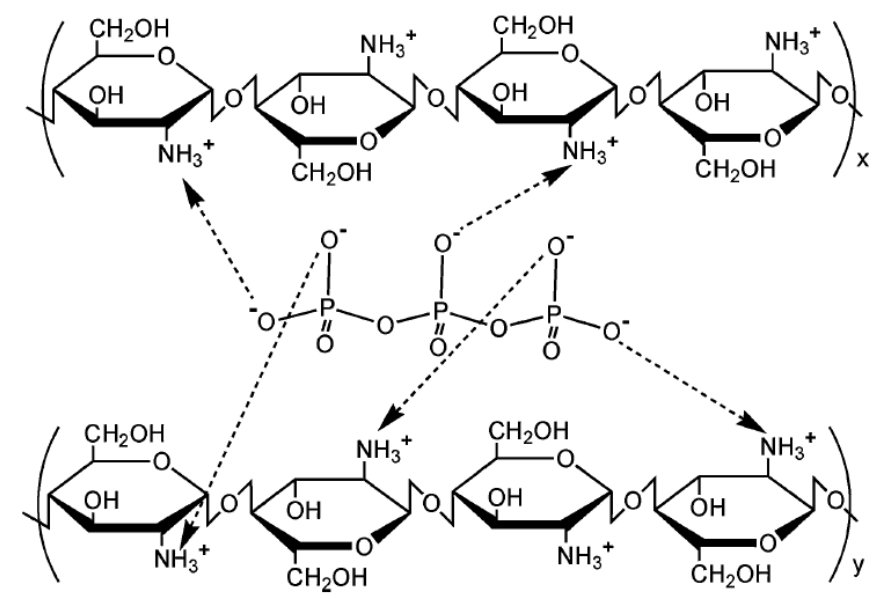

Source: Yang, et al., 2009

Fig. 7: Cross-link reaction mechanisms between chitosan and TPP

\section{Genipin}

Genipin is a compound isolated from the fruit of Gardenia jasminoides ELLIS, with its parent compound geniposide. Genipin has been widely used as antiphlogistics and cholagogues in herbal medicine (Fujikawa, et al., 1987). Genipin is about 5000-10000 times less cytotoxic than glutaraldehyde. Genipin have been used as agents cross link for the fixation of biological tissue as bioprostheses, and biocompatible genipin-fixed tissues were observed in some animals (Nishi, et 1., 1995; Sung et 
al., 1999; Sung et al., 2001). Different $\mathrm{pH}$ values make the reaction mechanism of cross link genipin and chitosan is different too. Under acidic and neutral conditions, a nucleophilic amino group of chitosan attacks the carbon atom olefins in the C-3, followed by open ring of dihydropyran and attacked by the amino group of the secondary on the newly formed aldehydo. genipin act as dialdehyde but the condensation products are more stable than glutaraldehyde. In the products, short chains of condensed genipin act as a cross-link bridges (Mi, et al., 2005; Shweta, and Sonia, 2013). Under alkaline conditions, the ring opening reaction of genipin occurs via nucleophilic attack by the hydroxyl ions in aqueous solution to form an intermediate aldehyde group later became aldol condensation. Aldehyde group at the end of genipin undergo polymerization reaction with the amino groups of chitosan Schiff to form a network of cross-links. Therefore, the $\mathrm{pH}$ conditions have an important role in reaction to cross link (Shweta, and Sonia, 2013). Figure 8 below is the reaction mechanism between Genipin with chitosan.

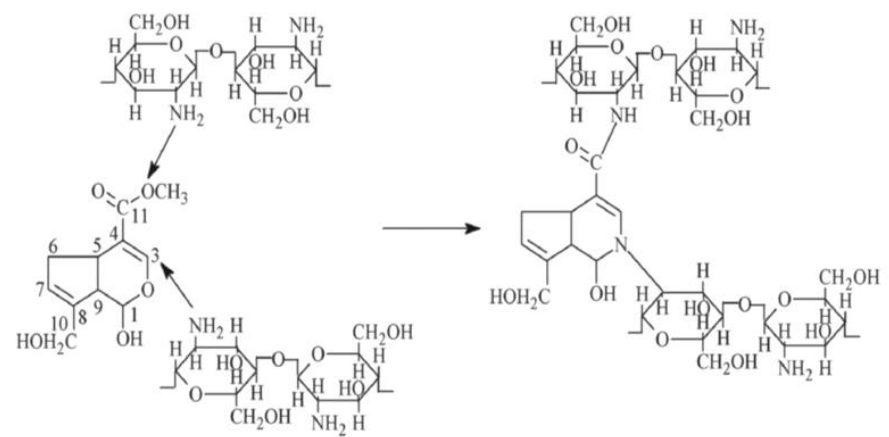

Source: Luo, et al., 2015

Fig. 8: Reaction mechanisms between genipin with chitosan

Under alkaline conditions, the ring-opening of genipin occurs via nucleophilic attack by the hydroxyl ions in aqueous solution to form intermediate aldehyde group later, then through aldol condensation. Aldehyde groups on the polymerization genipin undergo a Schiff reaction with the amino group of chitosan to form a network of cross-links. Therefore the $\mathrm{pH}$ value plays an important role in influencing cross reactions

\section{Solvent evaporation}

Solvent evaporation method is probably the best encapsulation method most widely used. This method can control the particle size ranging from micrometers to the nanometer. High efficiency and low solvent residue content can be achieved by considering several things, namely the selection of materials and a wide range of conditions. some variables that may affect the method of evaporating the solvent is a type of solvent, solvent volume, the ratio of the drug and the polymer, the rate of removal of solvent, the effect of the volume of aqueous phase internally in terms of solvent evaporation followed by multiple emulsions, the effect of adding a buffer or salt into the internal or external phase which can affect the microsphere size and pattern of drug release from the microspheres (Tiwari and Verma, 2011). The selection method of encapsulation by evaporation of the solvent depends on the nature of the hydrophilic or hydrophobic nature of the drug. Encapsulation process with solvent evaporation method can also be performed on oleoresin. The nature of the oleoresin is not soluble in water, so that the method used is the method of emulsion oil in water $(\mathrm{O} / \mathrm{W})$. This method is fairly simple consisting of (1) the dissolution of the hydrophobic drug in an organic solvent containing a polymer; (2) emulsification of the organic phase, called the dispersed phase, the aqueous phase is called the continuous phase; (3) solvent extraction of the dispersed phase by the continuous phase, accompanied by evaporation of the solvent, changing the dispersed phase droplets into solid particles; and (4) recovery and drying of the microspheres to remove residual solvent, and illustrated in Figure 9 (Li, et al., 2008).

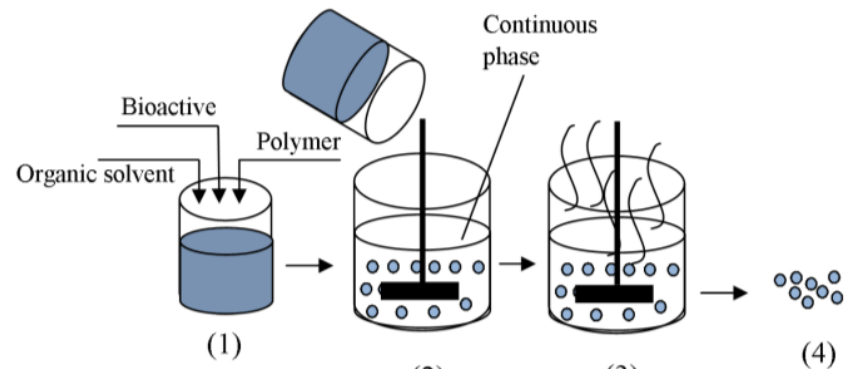

Source: Li, et al., 2008

(2)

(3)

Fig. 9: Basic principles of microencapsulation by solvent evaporation

Method of solvent evaporation can also be done with multiple emulsions such as water in oil in water $(\mathrm{W} / \mathrm{O} / \mathrm{W})$, oil in water-in-oil (O/W/O), water-in-oil-in-oil (W/O / O) and can also be water-in-oil-in-oil-in-oil (W/O/O/O). Figure 1 illustrates the process of encapsulation by solvent evaporation.

\section{Spray congealing}

Sprays congealing, known as prilling, spray chilling which is a process in which a mixture of hot melted sprayed using an atomizer in a cooling chamber where the droplets then become congeals and form solid particles. Liquid mixture consisting of one or more active principles, which can melt, dispersed or dissolved in a molten matrix material (Oh, et al., 2014). Spray congealing is part of encapsulation, because bioactive embedded in spraycongealed microparticles (Oh, et al., 2014; Ghebre-Sellassie, 1989). Spray congealing is the encapsulation method that can be used for medicine, food, flavor and drug delivery (Deasy, 1984; Gibbs, et al., 1999; Tobı'o, et al., 1999; Thies, 1996; Oh, et al., 2014). Schematic diagram of the principle of spray congealing can be shown in Figure 10. The first, a matrix material is heated at a temperature between $10-20^{\circ} \mathrm{C}$ above their melting point and bioactive material included in the liquid matrix with constant stirring. Liquid mixture then flowed into the atomizer which will spread as a fine spray into a chamber. Spherical liquid droplet is then cooled to a temperature below the melting point of the matrix material using cold air. Heat will be transferred from the droplets so that it will form solid spherical particles (Oh, et al., 2014). 

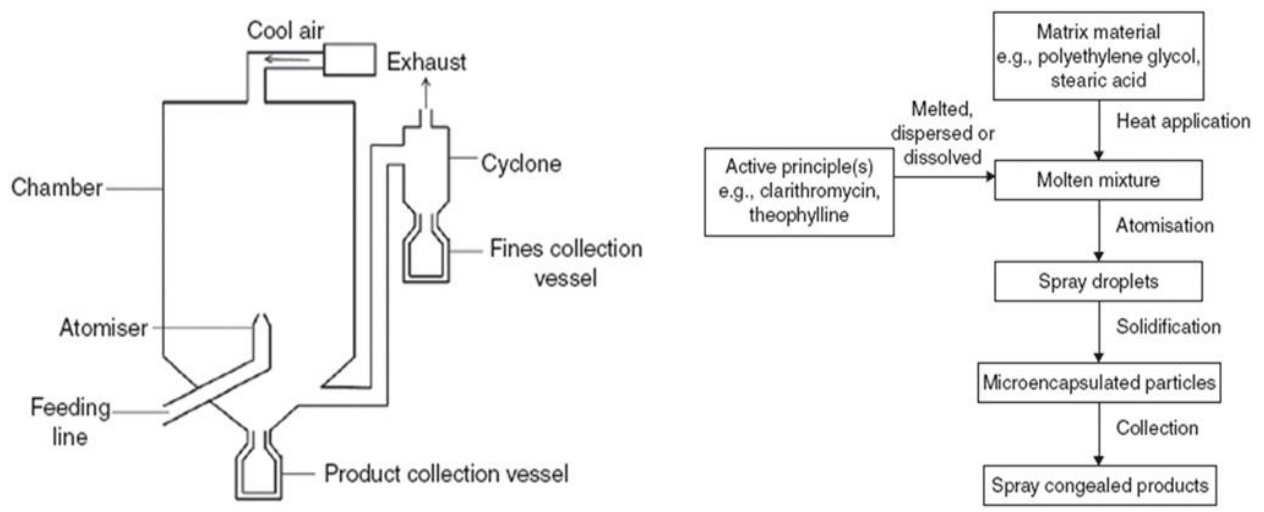

Source: Oh et al., 2014

Fig. 10: Schematic diagram of the spray-congealing process.

\section{CHITOSAN AS WALL MATERIAL OF ENCAPSULATION}

Bioactive Components of protection through the encapsulation process using a coating or wrapping. The process of encapsulation of bioactive, the coating must not react with active ingredients that protect, easily handled, low viscosity at high concentrations, have a stabilizing both the phase of emulsions and have a controlled release of the well, so as to achieve a targeted (Madene, 2006).

There are a couple of the coating material that does not meet the criteria of an ideal coating then have to be combined or modified by combining two or more of the coating material, in order to obtain the coating are physically and chemically better than the single coating (Poshadri and Kuna, 2010). Table 7 shows some wall material type that is often used in the encapsulation process.

Table 7: Type of wall material for encapsulation process.

\begin{tabular}{lll}
\hline \multicolumn{1}{c}{ Type } & \multicolumn{1}{c}{ Wall material } & \multicolumn{1}{c}{$\begin{array}{c}\text { Enkapsulation } \\
\text { method }\end{array}$} \\
\hline Carbohydrate & $\begin{array}{l}\text { Starch, maltodextrin, chitosan, } \\
\text { corn syrup, dextrin, starch } \\
\text { modification }\end{array}$ & $\begin{array}{l}\text { Spray- and freeze- } \\
\text { drying, extrusion, } \\
\text { coacervation, inclusion }\end{array}$ \\
\hline Cellulose & $\begin{array}{l}\text { Carboxymethyl, } \\
\text { cellulose,methyl, cellulose, } \\
\text { ethylcellulose, cellulose }\end{array}$ & $\begin{array}{l}\text { Coacervation, spray- } \\
\text { drying,and edible films }\end{array}$ \\
& $\begin{array}{l}\text { acetate-phthalate, cellulose } \\
\text { acetate, butylate- phthalate }\end{array}$ \\
\hline Gum & $\begin{array}{l}\text { Gum acacia, agar, sodium } \\
\text { alginate, carrageenan }\end{array}$ & $\begin{array}{l}\text { Spray-drying, metode } \\
\text { syringe (gel beads) }\end{array}$ \\
\hline Lipids & $\begin{array}{l}\text { Wax, paraffin, beeswax, } \\
\text { diacylglyerols, oils, fats }\end{array}$ & $\begin{array}{l}\text { Emulsion, liposomes, } \\
\text { film formation }\end{array}$ \\
\hline Protein & $\begin{array}{l}\text { Gluten, casein, gelatin, } \\
\text { albumin, peptides, peptides }\end{array}$ & Emulsi, spray-drying \\
Source: (Desai and Park, 2005; Poshadri and Kuna, 2010)
\end{tabular}

One of the coating materials that can be used for microencapsulation process is chitosan. Chitosan is biopolyaminosaccharide of the process of deacetylation of chitin, which is the largest source of polysaccharide after cellulose, derived from animal's arthropods and marine crustaceans and properties are biocompatible, biodegradable and non-toxic (Sinha, et al., 2004). Cellulose and chitin is a polysaccharide that two influential, plants produce cellulose in cell walls, while insects and crustaceans produce chitin in their shells (Muzzarelli, et al., 1986; Dumitriu, 1996). In Table 8 are several sources of chitin and chitosan (Nagahama, et al., 2008).

Table 8: Sources of chitin to produce chitosan

\begin{tabular}{lll}
\hline \multicolumn{1}{c}{ Sea animals } & \multicolumn{1}{c}{ Insects } & \multicolumn{1}{c}{ Microorganisms } \\
\hline Crustaceans & Scorpions & Green algae \\
Coelenterata & Brachiopods & Yeast (b-Type) \\
Annelida & Cockroaches & Fungi (cell walls) \\
Mollusca & Spiders & Mycelia penicillium \\
Lobster & Beetles & Brown algae \\
Shrimp & Ants & Chytridiaceae \\
Prawn & & Ascomydes \\
Krill & & Blastocladiaceae \\
Crab & & Spores \\
\hline
\end{tabular}

Source: Zargar et al., 2014.

Chitin is a homopolymer of 2-acetamido-2-deoxy-Dglucopyranose b-, and 2-amino-2-deoxy-b-D-glucopyranose which is deacetylation some glucopyranose residue. Chitosan is a polymer of glucopyranose form the residue in the form of deacetylation (Zarger, et al., 2014). The processing of chitosan from chitin are (1) Shrimp shell, (2) a reduction in size, (3) separation of proteins with $\mathrm{NaOH}$, (4) demineralized with $\mathrm{HCl}$, (5) washing and dewatering, (7) the removal of color, (8) chitin , (9) deacetylation of chitin with $\mathrm{NaOH}$, (10) washing and dewatering, (11) chitosan (Zargar, et al., 2014). Chitosan is obtained from chitin by eliminating the acetyl group and replace it with the amino group using an alkaline solution such as $\mathrm{NaOH}$, is called deacetylation process. Generally influence the process of substitution of acetyl group into amino group is $\mathrm{NaOH}$ concentration, temperature and reaction time. Reaction deacetylation of chitin in concentrations of $40 \% \mathrm{NaOH}$ at a temperature of $120^{\circ} \mathrm{C}$ for $1-3$ hours can produce $70 \%$ deacetylation of the chitosan. Figure 11 is processing of chitosan from chitin (Kumar, 2000; Zargar, et al., 2014). The chemical properties of chitosan include (Thakur and Thakur, 2014):

- Insoluble in water and organic solvents; soluble in dilute aqueous acidic solutions

- Linear aminopolysaccharide with too much nitrogen content 
- Weak base; deprotonated amino group acts a powerful nucleophile (pKa 6.3)

- Cationic biopolymer with high charge density (one positive charge per glucosamine residue)

- Enable to form hydrogen bonds intermolecularly; high viscosity

- Biological properties biocompatibility

- bioadhesivity

- bioactivity

- nontoxic

- biodegradable

- adsorbable

- $\quad$ antimicrobial activity (fungi, bacteria, viruses)

- $\quad$ antiacid, antiulcer, and antitumoral properties

- blood anticoagulants

- $\quad$ hypolipidemic activity

The role of chitosan begins developed in various industries such as the food industry, agriculture, cosmetic, pharmaceutical, health care, and for water treatment. Utilization of chitosan is widely applied in the pharmaceutical industry and the food, because it is not toxic and standards compliant foodstuffs are safe to consume (food grade). Many studies have proven the effectiveness of the use of chitosan in drug delivery systems and as a coating material on microencapsulation process (Bansal, et al., 2011).

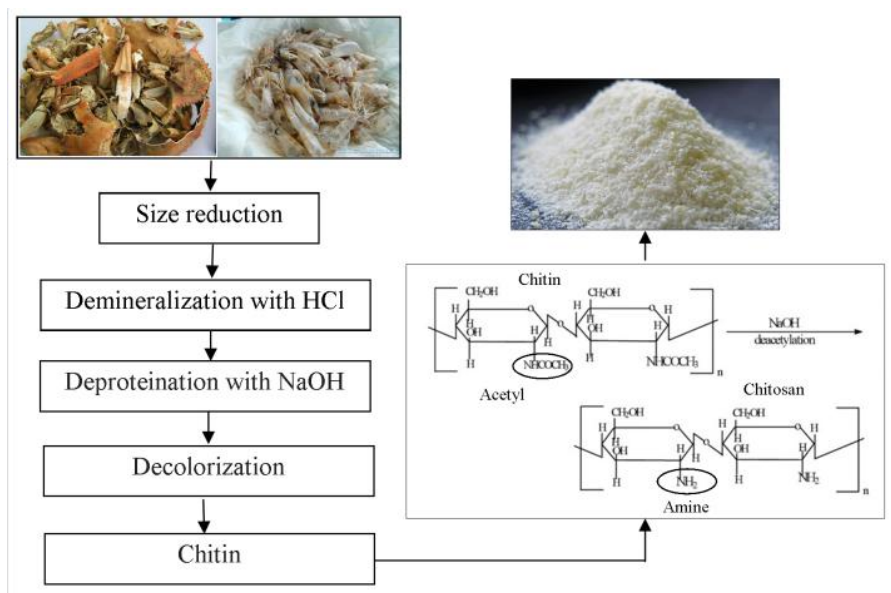

Fig. 11: Processing of chitin and chitosan

Use of chitosan is more and more on studies using chitosan as encapsulation process. This suggests that chitosan is a wall material that is appropriate for the encapsulation process ginger oleoresin using the most widely used method is spray drying and coacervation.

\section{RELEASE MECHANISM}

Based on the characteristics of the physical and chemical properties of the polymer, the mechanism of drug release from the polymer matrix can be categorized into three main processes (Leong and Langer, 1987), namely:

1. Diffusion of drugs from non-degradable polymer (diffusion control system)

2. The level of drug diffusion with swelling polymer (swelling system that controls)

3. Release of drug from degradation and erosion (erosion control system)

The terms of control release is the delivery of compounds in response to something such as $\mathrm{pH}$, enzymes, light, temperature, magnetic (Mishra, 2016). The main function was to control the release encapsulation of an active ingredient that is commonly used in the pharmaceutical industry. Control release can also be used in the food and beverage industry, cosmetics industry and agriculture.

One of the factors that influence the control release is a type of coating material used in encapsulation. Release method can be done with a diffusion method, which is controlled by the solubility and permeability of the matrix component in the matrix. (Crank, 1975; Cussler, 1997; Madene, et al., 2006). Another method is to degradation, which consists of a homogeneous release with a uniform velocity on the entire matrix and heterogeneous bounded by a thin layer on the surface of the delivery system (Pothakamury and Barbosa-Canovas, 1995).

Release mechanism relating to the release velocity can be calculated with the release kinetics. Here are some models that can be used to determine the rate of release in the process of encapsulation:

\section{Zero order kinetics}

A model release with zero order kinetics indicates that the dissolution of drugs from pharmaceutical dosage forms which does not separate and release slowly (the assumption is an area that has not changed and there is no equilibrium conditions) (Dash, et al., 2010; Costa and Lobo, 2001), zero-order release kinetics equation is:

$Q_{0}-Q_{t}=k_{0} t$

Can be rearranged into equation

$Q_{t}=Q_{0}+k_{0} t$

Where $Q_{t}$ is the amount of drug dissolved during the time $t$ and $Q_{0}$ is the number of drug in solution, to order zero then $\mathrm{Q}_{0}=0$ at time $\mathrm{t}$ and $\mathrm{k}_{0}$ is constant zero-order release in the concentration/time.

\section{First order kinetics}

This model was first introduced by Gibaldi and Feldman (1967) and Wagner (1969). This model also uses the illustration of absorption and / or elimination of some drugs (Gibaldi and Perrier, 
1982; Costa and Lobo, 2001). The phenomenon of dissolution of solid particles in liquid media implies the action of the surface, as can be seen by the Noyes-Whitney equation illustrated in Figure 12.

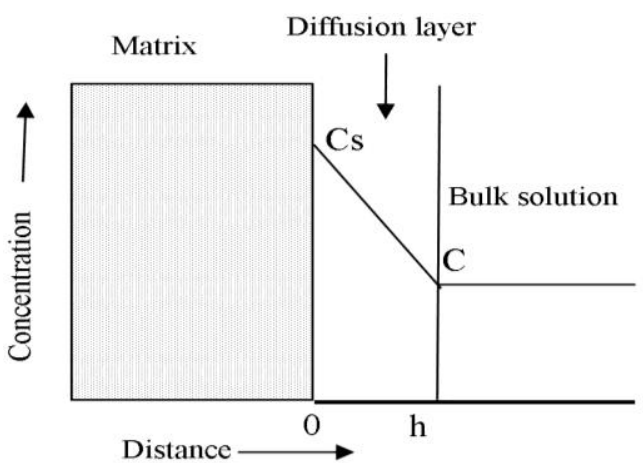

Fig. 12: The dissolution rate of homogeneous matrix system

Drug release followed the first order kinetics can be expressed by the equation:

$$
\begin{aligned}
& \frac{d C}{d t}=k\left(C_{s}-C\right) \\
& W=C . V
\end{aligned}
$$

$\mathrm{V}$ is the volume of liquid dissolution and $\mathrm{h}$ is the thickness of the diffusion layer. Hixson and Crowell adopted the Noyes-Whitney equation as follows:

$$
\begin{gathered}
V \frac{d C}{d t}=k V\left(C_{s}-C\right) \\
\frac{d(V C)}{d t}=k\left(V . C_{s}-V . C\right) \\
\frac{d W}{d t}=k\left(V . C_{s}-W\right) \\
W=V C_{s}\left(1-e^{-k t}\right) \\
\log \left(V C_{s}-W\right)=\log V C_{s}-\frac{k t}{2,303} \\
W_{0}=V C_{s} \\
\log \left(W_{0}-W\right)=\log W_{0}-\frac{k t}{2,303} \\
\log \left(W_{t}\right)=\log W_{0}-\frac{k t}{2,303}
\end{gathered}
$$

Equation 12 can be rewritten into:

$$
\begin{aligned}
& W_{t}=Q_{t} \\
& W_{0}=Q_{0} \\
& \quad \log Q_{t}=\log Q_{0}-\frac{k_{1} t}{2,303}
\end{aligned}
$$

\section{Higuchi model}

This release kinetics model refers to a model developed by Higuchi, 1961. In Figure 13 do graphical analysis of simple mass balance, Higuchi equation derived by the following equation for the amount of drug depleted or release per unit area, dQ because of the movement of the front $\Delta h$.

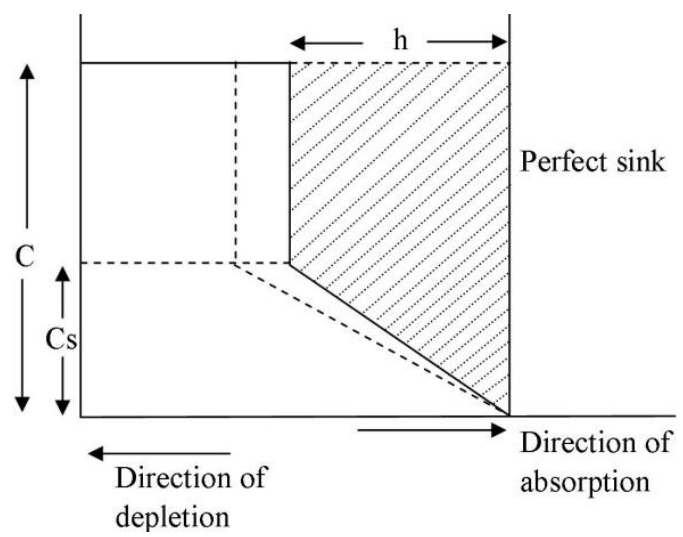

Fig. 13: The theoretical concentration of drug in the matrix system

$d Q=\left(C-C_{s}\right) d h+\frac{1}{2} C_{s} d h=A d h-\frac{1}{2} C_{s} d h$

Based on Fick's law :

$$
\frac{d Q}{d t}=D \frac{C_{s}}{h}
$$

Or

$$
\begin{aligned}
& C \frac{d h}{d t}-\frac{1}{2} C_{S} \frac{d h}{d t}=D \frac{C_{S}}{h} \\
& \frac{\left(2 A-C_{S}\right) h}{2 D C_{S}} d h=d t
\end{aligned}
$$

By integrating both sides will be obtained:

$$
t=\frac{h^{2}}{4 D C_{S}}\left(2 C-C_{s}\right)+K
$$

$\mathrm{K}=0$ for $\mathrm{t}=0$, so that the equation becomes:

$$
\begin{aligned}
& t=\frac{h^{2}}{4 D C_{s}}\left(2 C-C_{s}\right) \\
& h=2 \sqrt{\frac{4 D C_{s}}{\left(2 C-C_{S}\right)}}
\end{aligned}
$$

Based on Figure 11, the number of depletion $\mathrm{Q}$ at time $\mathrm{t}$ is:

$$
Q=h C-\frac{h C_{S}}{2}
$$

By substituting $\mathrm{h}$ from the equation 20 to equation 21 will get the following equation:

$Q=\left(C-\frac{C_{s}}{2}\right) 2 \sqrt{\frac{4 D C_{s}}{\left(2 A-C_{s}\right)}}=\sqrt{\operatorname{Dt}\left(2 C-C_{s}\right) C_{s}}$ 
To study the dissolution of planar heterogeneous matrix systems, where the drug concentration in the matrix is lower than the solubility and the release occurs through pores in the matrix, expression is given by equation (Dash, et al., 2010), so the equation becomes:

$$
Q=\sqrt{\frac{D \delta}{\tau}\left(2 C-\delta C_{s}\right) C_{s} t}
$$

Where $\mathrm{D}$ is the diffusion coefficient, $\delta$ is the matrix porosity, $\tau$ is the tortuosity, $\mathrm{Q}$ is the the amount of drug released at time $\mathrm{t}, \mathrm{C}$ is the initial concentration of the drug, $\mathrm{Cs}$ is the solubility of drug in the matrix. In general, the model can be made simple Higuchi (Dash, et al., 2010; Costa and Lobo, 2001) as the following equation 24:

$$
Q=k_{H} t^{\frac{1}{2}}
$$

Where $k_{H}$ is Higuchi dissolution constants

\section{Korsmeyer-Peppas model}

Korsmeyer, et al., 1983 developed a simple equation exponential relationship between the releases of drugs on time:

$$
f_{t}=a t^{n}
$$

Ritter and Peppas, 1987 also uses semi-empirical equations to show the process of diffusion Fickian release or non Fickian.

$$
\frac{M_{t}}{M_{\infty}}=k t^{n}
$$

Where $\mathrm{k}$ is a constant characteristic of the incorporation of the network system and drugs, $\mathrm{n}$ is an exponential diffusion is the description of the transport mechanism. Equation 31 is valid for the first $60 \%$ of the fraction of the release. Fickian diffusion occurs if the value of $n=0.5$ and non Fickian with $n>0.5$.

Ritger and Peppas, 1987 developed a semi-empirical equation to determine the release in the form of a sphere. To release the radial dimension of the sphere with radius a, the initial and boundary condition is perfect sink, the diffusion coefficient D, according to Fick's second law can be written:

$$
\frac{\partial C}{\partial t}=D\left[\frac{\partial^{2} C}{\partial r^{2}}+\frac{2}{r} \frac{\partial C}{\partial r}\right]
$$

Where

$$
t=0 \quad 0<r<a \quad C=C_{1}
$$$$
t>0 \quad r=a \quad C=C_{0}
$$

Solution of Fick's law with the boundary condition of equation 27 is:

$$
\frac{M_{t}}{M_{\infty}}=1-\frac{6}{\pi^{2}} \sum_{n=1}^{\infty} \frac{1}{n^{2}} \exp \left[\frac{-D n^{2} \pi^{2} t}{a^{2}}\right]
$$

Alternative solutions are used for the interpretation of the short time behavior are:

$$
\begin{aligned}
& \frac{M_{t}}{M_{\infty}}=6\left[\frac{D t}{a^{2}}\right]^{1 / 2}\left[\frac{1}{\pi^{\frac{1}{2}}}+2 \sum_{n=1}^{\infty} i \operatorname{erfc} \frac{n a}{\sqrt{D . t}}\right]-3 \frac{D . t}{a^{2}} \\
& \frac{M_{t}}{M_{\infty}}=6\left[\frac{D t}{\pi a^{2}}\right]^{1 / 2}-3 \frac{D . t}{a^{2}}
\end{aligned}
$$

Graphic comparison between equations 27 to 30 show the equation 30 with $\mathrm{n}=0.5 \mathrm{k}=6\left(\mathrm{D} / \pi a^{2}\right)^{1 / 2}$ gave $a t^{1 / 2}$ is only valid for the first $10-15 \%$ of the total drug release, once again at $a t^{1 / 2}$ cannot be used to analyze the data release solute from a spherical form.

According Ritger and Peppas, 1987 equations 31 with $60 \%$ of the first fraction releases can be used to determine the release of a cylindrical shape and a sphere, Peppas (1985) also contains the limit values are exponentially (n) for the cylinder and the ball shows the characterization of the mechanism of release are different can be seen in Table 9 .

Table 9: Exponents diffusional and diffusional release mechanism from various control systems release of non-swellable

\begin{tabular}{llll}
\hline \multicolumn{2}{c}{ Diffusion exponential, $\mathbf{n}$} & \multirow{2}{*}{ Release mechanism } \\
\cline { 1 - 3 } Thin Film & $\begin{array}{c}\text { Cylindrical } \\
\text { samples }\end{array}$ & $\begin{array}{c}\text { Sphere } \\
\text { samples }\end{array}$ & \\
\hline 0,5 & 0,45 & 0,43 & Diffusion Fickian \\
$0,5<\mathrm{n}<1$ & $0,45<\mathrm{n}<1$ & $0,43<\mathrm{n}<1$ & Non Fickian \\
1,0 & 1,0 & 1,0 & Zero-order release \\
\hline
\end{tabular}

\section{Hixson-Crowell model}

Hixson and Crowell (1931) formulated that the particle reguler area is proportional to the cubic root of the volume, equations obtained are as follows.

$$
W_{0}^{1 / 3}-W_{t}^{1 / 3}=K_{s} t
$$

Where $W_{0}$ is the initial of drug, $W_{t}$ is the remaining amount of the drug at time $\mathrm{t}$ and $K_{S}$ is constants that connect the surface-volume relation.

The protection of ginger oleoresin against environmental influences is by encapsulation using chitosan coating. In Figure 14 is a schematic diagram of ginger oleoresin encapsulation process with chitosan as wall materials.

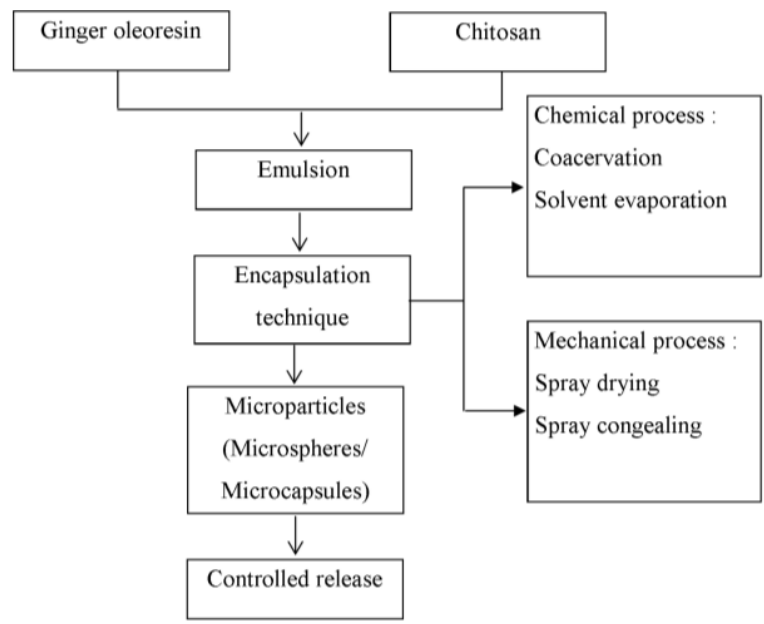

Fig. 14: Schematic diagram of encapsulation ginger oleoresin with chitosan as wall material 


\section{CONCLUSION}

Microencapsulation process is used for the protection and controlled release of ginger oleoresin is expected to be maintained during storage. The most widely used method is spray dryin, coacervation, solvent evaporation and spray congealing with a coating of chitosan, because it's safe to eat also biocompatible and biodegradable. Release kinetics model that can be used as a model zero order, first order, Higuchi models, Korsmeyer-Peppas models and Hixson-Crowell model.

\section{ACKNOWLEDGEMENTS}

Acknowledgements to the Ministry of Research, Technology and Higher Education on funds provided through BPPDN (Beasiswa Pendidikan Pascasarjana Dalam Negeri) in 2015.

\section{Financial support and sponsorship: Nil.}

Conflict of Interests: There are no conflicts of interest.

\section{REFERENCES}

Ali BH, Blunden B, Tanira MO, Nemmar, A. Some phytochemical, pharmacological and toxicological properties of ginger (Zingiber officinale Roscoe): A review of recent research. Food Chem Tox. 2008; 46: 409-20.

Alvim ID, Grosso CRF. Microparticles obtained by complex coacervation: influence of the type ofreticulation and the drying process on the release of the core material. Ciênc. Tecnol. Aliment., Campinas. 2010; 30: $1069-76$

Anandharamakrishnan C, Padma IS. 2015. Techniques for Food Ingredient Encapsulation. IFT Press. Wiley-Blackwell. UK. pp. 1-9.

Anderson PJ. Purification and quantitation of glutaraldehyde and its effect on several enzyme activities in skeletal muscle. J Histochem Cytochem. 1967. 15: 652-61.

Arshady R. 1999. Microspheres, microcapsules and liposomes. In: Arshady R, ed. Preparation and Chemical Applications. Vol. I. UK: Citus Books. London. pp. 279-322.

Bakry AM, Abbas S, Ali B, Majeed H, Abouelwafa MY, Mousa A, Liang L. Microencapsulation of Oils: A Comprehensive Review of Benefits, Techniques, and Applications. Comp Rev Food Sci Food Safety. 2016; 15: 143-82.

Bailey-Shaw YA, Williams L, Junor G, Green CE, Hibbert SL, Salmon C, Smith AM. Changes in the contents of oleoresin and pungent bioactive principles of Jamaican ginger (Zingiber officinale Roscoe) during maturation. J Agri Food Chem. 2008; 56: 5564-71.

Balasubramani P, Viswanathan R, Vairamani M. Response surface optimisation of process variables for microencapsulation of garlic (Allium sativum L.) oleoresin by spray drying. Biosys Eng. 2013; 114: 205-13.

Bansode SS, Banarjee SK, Gaikwad SL, Jadhav R, Thorat, RM. Microencapsulation : A Review. Int J Pharm Sci Rev Res. 2010; 1: 38-43

Bhattarai S, Tran VH, Duke CC. Stability of [6]-gingerol and [6]-shogaol in simulated gastric and intestinal fluids. J Pharm Biomed Analysis. 2007; 45: 648-53

Blauer G, Harmatz D, Meir E, Swenson MK, Zvilichovsky B. The interaction of glutaraldehyde with poly( $\alpha, \mathrm{L}$-lysine), $n$-butylamine, and collagen. I. The primary proton release in aqueous medium. Biopolym. 1975; 14: 2585-98.

Bowers JH, Cater CW. The reaction of glutaraldehyde with proteins and other biological materials. J Royal Microscop Soc. 1966; 85: 193-200.
Burgess DJ, Ponsart S. beta-Glucuronidase activity following complex coacervation and spray drying microencapsulation. J Microencapsulation. 1998; 15: 569-79.

Cerqueira MA, Costa MJ, Rivera MC, Ramos ÓL, Vicente, AA. 2015. Flavouring and Coating Technologies for Preservation and Processing of Foods. In: Conventional and Advanced Food Processing Technologies. 1st ed. John Wiley \& Sons, Ltd. UK. pp. 267311.

Connell DW, Sutherland MD. A re-examination of gingerol, shogaol and zingerone, the pungent principles of ginger (Zingiber officinale Roscoe). Australian J Chem. 1969; 22: 1033-43.

Costa P, Lobo JMS. Modeling and comparison of dissolution profiles. Euro J Pharm Sci. 2001; 13: 123-33.

Crank J. 1975. The Mathematics of Diffusion. 2nd ed. Clarendon Press, Oxford

Cussler EL. 1997. Diffusion, Mass Transfer in Fluid Systems, 2nd edition. Cambridge: Cambridge University Press.

Dash S, Murthy PN, Nath L, Chowdhury P. Kinetic modeling on drug release from controlled drug delivery systems. Act Pol Pharm. 2010. 67: 217- 23

Deasy PB. 1984. General introduction. In: Deasy PB, editor. Microencapsulation and related drug processes. Marcel Dekker, New York. pp. 1-193

Desai KGH, Park HJ. Preparation and characterization of drugloaded chitosan-tripolyphosphate microspheres by spray drying. Drug Dev Res. 2005; 64: 114-28

De Villiers MM. 2005. Oral Conventional Solid Dosage Forms: Powders and Granules, Tablets, Lozenges, and Capsules. In: Theory and Practice of Contemporary Pharmaceutics. CRC Press LLC. New York. pp. 314-23.

Dubey R, Shami TC, Rao KUB. Microencapsulation Technology and Applications. Defence Sci J. 2009; 59: 82-95

DumitriuS. 1996. Polysaccharides in Medicinal Applications, CRC Press, Boca Raton, FL

Dziezak JD. Microencapsulation and encapsulated ingredients. Food Tech. 1988; 28:138.

Fujikawa S, Yokota T, Koga K, Kumada J. The continuous hydrolysis of geniposide to genipin using immobilized $\beta$-glucosidase on calcium alginate gel. Biotech Lett. 1987; 9: 697-702

Ghosh SK. 2006. Functional coatings and microencapsulation: A general perspective, Chap 1. Wiley-VCH, Verlag $\mathrm{GmbH}$ and $\mathrm{Co}$. KGoaA, Weinheim.

Gharsallaoui A, Roudaut G, Chambin O, Voilley A, Saurel R. Applications of spray-drying in microencapsulation of food ingredients: An overview. Food Res Int. 2007; 40: 1107-21.

Gibaldi M, Feldman S. Establishment of sink conditions in dissolution rate determinations-theoretical considerations and appliparameters cation to nondisintegrating dosage forms. J Pharm Sci. 1967; 56: 1238-42.

Gibaldi M, Perrier D. 1982. Pharmacokinetics, Drugs and the Pharmaceutical Sciences, 2nd Edition. Marcel Dekker, Inc, New York and Basel.

Gibbs BF, Kermasha S, Alli I, Mulligan CN. Encapsulation in the food industry: a review. Int J Food Sci Nutr. 1999; 50:213-24

Gonçalves VL, Laranjeira MCM, Fávere VT. Effect of Crosslinking Agents on Chitosan Microspheres in Controlled Release of Diclofenac Sodium. Polímeros. 2005; 15: 6-12

Gutieerez J, Sede-No-Noda A, Colebrook M, Sicilia J. An efficient approach for solving the lot-sizing problem with time-varying storage capacities. European J Operational Research. 2008.Vol.189(3): $682-93$.

Harimurti N, Nhestricia N, Yuliani SS, Yuliania S. Effect of oleoresin concentration and composition of encapsulation materials on properties of microencapsulated ginger oleoresin using spray drying method. Ind J Agri. 2011; 4: 33-9

Higuchi T. Rate of release of medicaments from ointment bases containing drugs in suspension. J Pharm Sci. 1961; 50: 874-5

Jayakrishnan A, Jameela SR. Glutaraldehyde as a fixative in bioprostheses and drug delivery matrices. Biomaterials. 1996; 17: 471-84 
Jayanudin Barleany DR, Rochmadi, Wiratni, Sugiarti A, Kusuma YA, 2013. Modification on maceration extraction to the yield and components of red ginger oleoresin. Proceeding of International Conference on Chemical Engineering. Parahyangan University, December 4-5th. pp: $72-77$

Jyothi NVN, Prasanna PM, Sakarkar SN, Prabha KS, Ramaiah PS, Srawan GY. Microencapsulation techniques, factors influencing encapsulation efficiency. J Microencapsulation. 2010; 27: 187-97

Keshani S, Daud WRW, Nourouzi MM, Namvar F, Ghasemi M. Spray drying: An overview on wall deposition, process and modeling. J Food Eng. 2015; 146: 152-62

Ko JA, Hwang SJ, Park JB, Lee JS. Preparation and characterization of chitosan microparticles intende for controlled drug delivery. Int J Pharm. 2002; 249: 165-74

Korsmeyer RW, Gurny R, Doelker EM, Buri P, Peppas NA. Mechanism of solute release from porous hydrophilic polymers. Int $\mathrm{J}$ Pharm. 1983; 15: 25-35

Kruif, C.G. Weinbreck, F. and Vries, R. 2004. Complex coacervation of proteins and anionic polysaccharides. Current Opinion in Colloid and Interface Science. 9: 340-9

Kumar MNVR. A review of chitin and chitosan applications. Reactive Func Polym. 2000; 46: 1-27

Lemetter CYG, Meeuse FM, Zuidam NJ. Control of themorphology and the size of complex coacervate microcapsules during scale-up. AIChE J. 2009; 55:1487-96

Leong KW, Langer R. Polymeric controlled Drug Delivery, Adv Drug Deliv Rev. 1987; 1: 199-233

Li M, Rouaud O, Poncelet D. Microencapsulation by solvent evaporation: State of the art for process engineering approaches. Int $\mathbf{J}$ Pharm. 2008; 363: 26-39

Lun LC, Derong T, Le L. Research on the extracting and antioxidation dynamic characteristics of ginger oleoresin. Int J Food Sci Tech. 2008; 43: 517-25

Luo M, Peng H, Deng Z, Yin Z, Zhao Q, Xiong H. Preparation and Characterization of Genipin-Crosslinked Chitosan Microspheres for the Sustained Release of Salidroside. Int J Food Eng. 2015; 11: 323-33

Madene A, Jacquot M, Scher J, Desobry S. Flavour encapsulation and controlled release - a review. Int J Food Sci Tech. 2006; 41: $1-21$

Magalhaes MT, Koketsu M, Goncalves SL, Cornejo FEP, Marques LMR. Brazilian ginger (Zingiber officinale Roscoe): General aspects, essential oil and oleoresin. 2. Drying essential oil and oleoresin. Food Sci Tech (Campinas). 1997; 17: 132-6.

Mi, FL, Shyu SS, Peng CK. Characterization of ring-opening polymerization of genipin and $\mathrm{pH}$-dependent cross-linking reactions between chitosan and genipin. J Polym Sci. 2005; 43:1985-2000.

Mishra, M. 2016. Handbook of Encapsulation and Controlled Release. CRC Press Taylor \& Francis Group. New York. pp. 4-15.

Mishra P, Mishra S, Mahanta CL. Effect of maltodextrin concentration and inlet temperatureduring spray drying on physicochemical and antioxidant properties of amla (Emblica officinalis) juice powder. Food Bioprod Process. 2014. 92:252-8

Murthy, Pushpa S., Gautam, Ranju., J, Pura Naik. Ginger oleoresin chemical composition, bioactivity and application as biopreservatives. Journal of Food Processing and Preservation. 2015. 39: 1905-12.

Muzzarelli RA, Jeuniaux C, Gooday, GW. 1986. Chitin in Nature and Technology, 1st ed., Plenum Press, New York

Nagahama H, Nwe N, Jayakumar R, Koiwa S, Furuike T, Tamura $\mathrm{H}$. Novel biodegradable chitin membranes for tissue engineering applications. Carbohydr. Polym. 2008. 73: 295-302.

Nielsen PV, Raos R. Inhibition of fungal growth on bread by volatile components from spices and herbs and the possible application in active packaging with special emphasis on mustard essential oil. Int J Food Microbio. 2000; 60: 219-29.

Nishi C, Nakajima N, Ikada Y. In vitro evaluation of cytotoxicity of diepoxy compounds used for biomaterial modification. J Biomed Materials Res.1995; 29: 829-34
Nixon JR, Khalil SAH, Carless JE. Phase relationship in the simple coacervating system isoelectric gelatine:ethanol:water. J Pharm Pharmacol. 1966; 18: 409-16

Nurlaili FA, Darmadji P, Pranoto Y. Mikroenkapsulasi oleoresin ampas jahe (Zingiber officinale var.Rubrum) dengan penyalut maltodekstrin. Agritech. 2014; 34: 22-8

Nwaoha M, Elizabeth I, Okafor, Ifeanyi G, Veronica AO. Production of oleoresin from ginger (Zingiber officinale) peels and evaluation of its antimicrobial and antioxidative properties. African $\mathbf{J}$ Microbio Res. 2013; 7: 4981-9

Oh CM, Guo Q, Heng PWS, Chan LW. Spray-congealed microparticles for drug delivery -an overview of factors influencing their production and characteristics. Expert Opin. Drug Deliv. 2014; 11: 1-14

Onyenekwe PC. Assessment of oleoresin and gingerol contents in gamma irradiated ginger rhizomes. Nahrung. 2000; 44: 130-2

Peppas NA. Analysis of Fickian and non-Fickian drug release from polymers. Pharm Acta Helv. 1985. 60:110-1

Poshadri A, Aparna K. Microencapsulation technology. J Res ANGRAU. 2010; 38: 86-102

Pothakamury UR, Barbosa-Cánovas GV. Fundamental aspects of controlled release in foods. Trends Food Sci Tech. 1995; 6: 397-406

Ritger PL, Peppas NA, 1987. A simple equation for description of solute release II. Fickian and anomalous release from swellable devices. J Controlled Rel. 1987; 5: 37-42

Ravindran PN, Sasikumar B, George JK, Ratnambal MJ, Normal Babu K, Zachariah TJ. Genetic resources of ginger (Zingiber officinale Rosc.) and its conservation in India. Plant Genet Resour Newslett. 1994; 98: 1-4

Reineccius GA. 1994. Flavor manufacturing. Part II. Flavor encapsulation.In Source Book of Flavors, Heath, H.B. ed. Chapman and Hall, New York, Chapter 11, pp. 605-25.

Risch SJ. 1995. Encapsulation: overview of uses and techniques. In: Rish SJ, Reineccius, G.A. ed. Encapsulation and Controlled Release of Food Ingredient. American Chemical Society. Washington, DC. pp. 2-7.

Saravanan M, Rao KP. Pectin-gelatin and alginate-gelatin complex coacervation for controlled drug delivery: Influence of anionic polysaccharides and drugs being encapsulated on physicochemical properties of microcapsules. Carbohyd Polym. 2010; 80:808-16

Schmitt C, Sanchez C, Desobry-Banon S, Hardy J. Structure and technofunctional properties of protein-polysaccharide complexes: A review. Crit Rev Food Sci Nut. 1998; 38: 689-753.

Shaikh J, Bhosale R, Singhal R. Microencapsulation of black pepper oleoresin. Food Chem. 2006. 94: 105-10.

Shahidi F, Han XQ. 1 Encapsulation of food ingredients. Crit Rev Food Sci Nut. 1993; 33: 501-47.

Shweta A, Sonia P. Pharmaceutical relevance of crosslinked chitosan in microparticulate drug delivery. Int Res J Pharm. 2013; 4: 4551 .

Simon-Brown K, Solval KM, Chotiko A, Alfaro L, Reyes V, Liu C, Dzandu B, Kyereh E, Barnaby AG, Thompson I, Xu Z, Sathivel S. Microencapsulation of ginger (Zingiber officinale) extract by spray drying technology. LWT/Food Sci Tech. 2016; 70: 119-25

Siow LF, Ong CS. Effect of pH on Garlic Oil Encapsulation by Complex Coacervation. J Food Process Tech. 2013; 4: 1-5

Stahl WM. Oleoresin quality analysis- fact or fiction?. Trop Sci. $1973 ; 14: 335-45$

Sutaphanit P, Chitprasert P. Optimisation of microencapsulation of holy basil essential oil in gelatin by response surface methodology. Food Chem. 2014; 150:313-20.

Sung HW, Chang Y, Chiu CT, Chen CN, Liang HC. Crosslinking characteristics and mechanical properties of a bovine pericardium fixed with a naturally occurring crosslinking agent. J Biomed Mater Res. 1999; 47: 116-26

Sung HW, Liang IL, Chen CN, Huang RN, Liang HF. Stability of a biological tissue fixed with a naturally occurring crosslinking agent (genipin). J Biomed Mater Res. 2001; 55: 538-46 
Thakur VK, Thakur MK, Recent Advances in Graft Copolymerization and Applications of Chitosan: A Review. ACS Sustainable Chem. Eng. 2014; 2: 2637-52

Thanoo BC, Sunny MC, Jayakrishnan A. Cross-linked Chitosan Microspheres: Preparation and Evaluation as a Matrix for the Controlled Release of Pharmaceuticals. J Pharm and Pharmacol. 1992; 44: 283-96

Thies C. 1996. A survey of microencapsulation processes. In: Benita S, editor. Microencapsulation: methods and industrial applications. Marcel Dekker, New York. pp. 1-20

Tiwari S, Verma P. Microencapsulation technique by solvent evaporation method (Study of effect of process variables). Int. J. of Pharm. \& Life Sci. 2011; 2: 998-1005

Tobi'o M, Schwendeman SP, Guo Y, McIver J, Langer R, Alonso MJ. Improved immunogenicity of a core-coated tetanus toxoid delivery system. Vaccine. 1999; 18: 618-22

Vaidya S, Bhosale R, Singhal RS. Microencapsulation of Cinnamon Oleoresin by Spray Drying Using Different Wall Materials. Drying Tech. 2006; 24: 983-92.

Vandelli MA, Rivasi F, Guerra P, Forni F, Arletti R. Gelatin microspheres crosslinked with d,l-glyceraldehyde as a potential drug delivery system: preparation, characterisation, in vitro and in vivo studies. Int J Pharm. 2001; 215: 175-84

Venkatesan $\mathrm{P}$, Manavalan R, Valliappan $\mathrm{K}$. Microencapsulation: A Vital Technique in Novel Drug Delivery System. Pharm Sci Res. 2009; 1: 26-32.

Vernin G, Parkanyi C. 2004. Chemistry of Ginger. in Ravindran, P.N. and Nirmal, K.Babu. Ginger. The Genus Zingiber. CRC PRESS. Boca Raton, Florida

Wagner JG. Interpretation of percent dissolved-time plots derived from in vitro testing of conventional tablets and capsules. J Pharm Sci. 1969; 58: 1253-57

Wohlmuth H, Leach DN, Smith MK, Myers S. Gingerol Content of Diploid and Tetraploid Clones of Ginger (Zingiber officinale Roscoe). J Agri Food Chem. 2005; 53: 5772-8
Yan M. 2016. Microencapsulation with Coacervation. In: Mishra, M. ed. Handbook of Encapsulation and Controlled Release. CRC Press Taylor \& Francis Group. US. pp. 235-43.

Yuliani S, Desmawarni, Harimurti, N, Yuliani, SS. Pengaruh laju alir umpan dan suhu inlet spray drying pada karakterisasi mikrokapsul oleoresin jahe. J Pascapanen. 2007; 4: 18-26

Zargar V, Asghari M, Dashti A. A Review on Chitin and Chitosan Polymers: Structure, Chemistry, Solubility, Derivatives, and Applications. ChemBioEng Rev. 2015; 2: 1-24

Zuidam NJ, Shimoni E. 2010. Overview of microencapsulates for use in food products or processes and methods to make them. In: Zuidam N.J, and Nedovic V.A. ed. Encapsulation technologies for active food ingredients and food processing. Chapter 2. New York: Springer Science + Business Media, LLC. 329

Zuidam NJ, Heinrich, E. 2010. Encapsulation of Aroma. In: Encapsulation Technologies for Active Food Ingredients and Food Processing. Springer Science+Business Media, LLC. New York. pp. 13135.

\section{How to cite this article:}

Jayanudin J, Rochmadi R, Fahrurrozi M, Wirawan SK. Microencapsulation Technology of Ginger Oleoresin With Chitosan as Wall Material: A review. J App Pharm Sci, 2016; 6 (12): 209-223. 